
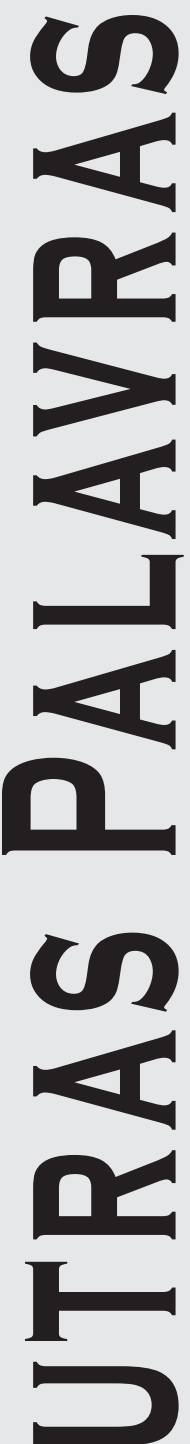

Revista Música Hodie, Goiânia - V.16, 232p., n.2, 2016 


\title{
A symphonic poem arrangement for piano and tamburitza orchestra by Ferenc Kovač
}

\author{
Slađana Marić (University of Novi Sad, Novi Sad, Sérvia) \\ sladana.elt@gmail.com
}

\begin{abstract}
The subject matter discussed in the text is a symphonic poem by Ferenc Kovač (KOVÁCS, 1948) titled "Ratna poema" (The War Poem) arranged for piano and tamburitza orchestra. The premiere performance of the piece by the pianist Slađana Marić and The Grand Tamburitza Orchestra of Radio-Television of Vojvodina, conducted by F. Kovač, was held on $24^{\text {th }}$ of May, 2011 in Novi Sad, Serbia. The main purpose of this research was to discuss this unique music piece in contemporary piano and tamburitza orchestra repertoire. Methodology was based on soft or research interview and analytical approach. The main conclusion was that, in general, this orchestral work with a solo piano, is a unique combination of memorable tunes, solid construction, and vivid orchestration. The analytical interpretations offered in this paper may be the first guidance for future interpretation or performance of the piece. Keywords: Kovač (Kovács) Ferenc; Musical analysis and performance; Piano Repertoire; Tamburitza Orchestra.
\end{abstract}

Um poema sinfônico para piano e orquestra de tamburitza por Ferenc Kovac

Resumo: O assunto abordado no texto é um poema sinfônico escrito por Ferenc Kovac (KOVAČ/KOVÁCS, 1948) intitulado "Ratna poema" (The War Poem) arranjado para piano e uma orquestra de tamburitza. A estreia deste poema sinfônico foi realizada pela pianista Slađana Marić e a Grande Tamboritza Orquestra de Radio Televisão de Vojvodina, sob a regência de F. Kovac, em 24 de Maio, 2011, em Novi Sad, Sérvia. Objetivo principal desta pesquisa foi discutir esta peça única no repertório contemporâneo de piano e orquestra de tamburitza. A metodologia foi baseada em entrevista de pesquisa (soft ou research interview) e abordagem analítica. A principal conclusão foi que, em geral, este poema sinfônico com um piano solo, é uma combinação única de melodias memoráveis, construção sólida e orquestração enérgica. As interpretações analíticas oferecidas no texto podem ser a primeira orientação para futuro a interpretação ou performance deste poema sinfônico.

Palavras-chave: Análise musical e performance; Kovac (Kovač/Kovács) Ferenc; Orquestra Tamburitza; Repertório pianístico.

Un poema sinfónico para piano y orquesta tamburitza por Ferenc Kovac

Resumen: Asunto discutido en el texto es uno poema sinfónico escrito por Ferenc Kovac (Kovač / Kovács, 1948) con el nombre "Ratna poema" (El Poema Guerra) para piano y orquesta tamburitza. Primera presentación de este poema sinfónico fue realizada por el pianista Sladana Maric (Slađana Marić) y Gran Tamboritza Orquesta de la Radio Televisión de Vojvodina dirigida por el maestro F. Kovac, el 24 de mayo de 2011, en Novi Sad, Serbia. Principal objetivo de este estudio fue informar sobre esta pieza única de música en el repertorio contemporáneo del piano y orquesta tamburitza. En este trabajo (artículo) la metodología utilizada se basó en la entrevista de investigación (soft o research interview) y el enfoque analítico. La principal conclusión fue que, en general, este poema sinfónico con un piano, es una combinación única de melodías memorables, buena construcción y la orquestación de colores vivos. Las interpretaciones analíticas que se ofrecen en el texto pueden ser la primera guía para la futura interpretación o presentación de este poema sinfónico.

Palabras clave: Análisis musical y performance; Kovac (Kovač/Kovács) Ferenc; Orquesta Tamburitza; Repertorio de piano.

There are still $21^{\text {st }}$ century contemporary living composers who can offer different sounds and pieces of music, on one hand, to satisfy their own compositional expressional needs, and on the other hand, to satisfy the performers and listeners, traditionalists in their devotion to the forms and sounds of centuries behind. One of them is Ferenc Kovač ${ }^{1}$ (Hungarian: Kovács ${ }^{2}$, born in Debeljača, Serbia, 19 Aug. 1948), composer, arranger, pianist and music producer. In Radio Novi Sad since 1969, producer of the Big Band Orchestra, etc. Composed light and jazz music for orchestra, music for children, pop songs and music for radio dramas. Winner of many awards (EBERST, 1997:52).

Aim of this work is to present, a unique music piece in contemporary piano and tamburitza orchestra repertoire in the field of composed classical music, the symphonic poem arrangement for piano and tamburitza orchestra ${ }^{3}$ titled "Ratna Poema" or "The War 
Poem” by Ferenc Kovač. The paper offers the possible guidance in future interpretation or performance of the piece, as well as the biographical and bibliographical presentation in English of the work of this composer.

With the intention of also gathering the information relevant for the national and international music historiography, we used the so-called soft interview or the research interview, as a method of scientific/musicological research. Through the research interview the aim was to get to know and acknowledge the way of thinking and the ideas of the creator of works during his life, so that his ideas would not be in the future incorrectly interpreted, and to better understand the musical turnovers and contrasts, or in other words, to find the proper "key" for their interpretation.

\section{The term "symphonic poem (tone-poem)"}

Categories of genre even today can have many levels of musical interpretation. Identifying the precise boundaries between individual genres can in many cases be problematic. As a part of the literature review, in the following part, we will offer some insights in the complexity of defining the symphonic poem and tone poem in music literature.

The symphonic poem or tone poem (Fr. poème symphonique, De. Sinfonische Dichtung, Esp./Por. Poema Sinfônico) is in many cases defined as a single continuous section (a movement) piece of orchestral music that represents a particular story line, or illustrates or evokes the content of a poem, novel, painting, landscape, or other (non-musical) source, rather than just conveying emotions or a general idea. LATHAM (2002) acknowledges that "while Liszt may have invented the symphonic poem and Richard Strauss brought it to its highest point, overall the form was less well received in Germany than in other countries". According to MOORTELE, (2008:49) "comparable adaptations of the model developed by Liszt appeared all over Europe throughout the second half of the nineteenth century (e.g., Camille SaintSaëns’s A-minor Cello Concerto, op. 33 and several of Bedřich Smetana’s symphonic poems)."

Symphonic poem is, thus, a single-movement orchestral composition with characteristic structure (without definite form or scheme, which involves blending and interweaving of sonata form and sonata cycles), relying on variation techniques and principles of exposition, and development of forms such as faithful reflection of non-music ideas and content where the themes and motives are the bearers of spiritual content and not the elements of architectural construction. Tone painting, musical symbolism and use of leitmotifs to some authors serve as means of painting nonmusical ideas and content. Many symphonic poems are between symphonies and musical dramas. Some composers, however, limit their symphonic poems to creating a general mood (KOVAČEVIĆ, 1977: 353).

In the following part, we present a summary of the definition of symphonic poem from The Harvard Dictionary of Music by Don Michael RANDEL (2003:855):

Symphonic poem (Fr. poème symphonique; Ger. symphonische Dichtung). An orchestral piece whose music is accompanied by a program, i.e., a text, generally poetic or narrative in nature, which is meant to be read by the audience before listening to the work. As is true for other types of program music, the program may be rather brief and vague (and may even consist merely of a suggestive title), or it may be long and detailed. Similarly, the music may be related to the program only very generally or in a myriad of specific ways. Usually the term is reserved for a composition in one movement, as opposed to the multi-movement program symphony; though many symphonic poems do contain several contrasting sections, these sections tend to flow into one another (through transitional passages) and are usually unified by tonal or motivic interrelationships. 
According to Latham (2002:1233) a symphonic poem (tone-poem) is a piece of orchestral music, usually in one movement, based on a literary, poetic, or other extra-musical idea. It originated in the mid $19^{\text {th }}$ century with Liszt and, as a direct product of a Romantic movement which encouraged literary, pictorial, and dramatic associations in music, it developed into an important form of programme music in the second half of the $19^{\text {th }}$ century. Elements of symphonic architecture could be compressed into its single-movement form, and although the term 'tone-poem' has largely been used interchangeably with 'symphonic poem', a few composers, notably Richard Strauss and Sibelius, have preferred the former for pieces that are less 'symphonic' in design and in which there is no special emphasis on thematic or tonal contrast.

GRIMLEY (2004:95) defines the tone poem, as a single continuous section (a movement) piece of orchestral music, is concerned at a fundamental level with the evocation of a particular mood or atmosphere, or with the articulation of an extra-musical narrative or programme. They are characterised by their freer, innovative approach to musical form, particularly the tendency towards structures that telescope the traditional four-movement scheme of a symphony into a single musical span.

In the book MUSICA, a symphonic poem is defined as a type of "program" music which tell a story, describe or depict something outside music, such as a storm or a rural landscape (ASHKENAZY (Ed.), 2010:192), while a tone-poem, also known as a "symphonic poem", is defined as large orchestral work, usually in one extended movement, with the scope of a symphony but free in form (ASHKENAZY (Ed.), 2010:499).

The most recent definition with historic development and example titles is given in the 2013 edition of The Oxford Dictionary of Music, by (Eds.) Michael Kennedy, Tim Rutherford-Johnson and Joyce Kenned, where the distinctions between the terms symphonic poem, tone poem and sound poem were introduced, and examples of pieces up to the late $21^{\text {st }}$ century were given (words marked in bold by the author).

Symphonic poem (sinfonische Dichtung [Ger.]) is a descriptive term applied by Liszt to his 13 one-movement orchestral works, which, while on a symphonic scale were not 'pure' symphonies because they dealt with descriptive subjects taken from classical mythology, Romantic literature, recent history, or imaginative fantasy, e.g. Prometeus, Mazeppa, Les Préludes, etc. In other words they were 'programmatic'. Other composers followed his line, e.g. Smetana (Wallenstein's Camp, etc.), Tchaikovsky (Francesca da Rimini, etc.), Saint-Saëns (Le Rouet d'Omphale, etc.), Franck (Le chasseur maudit, etc.), and many others. Richard Strauss, who carried pictorialism a stage further, preferred the term Tondichtung for his works in this form (Don Juan, etc.). This is usually translated as 'tone-poem', but it has been well suggested that 'sound-poem' comes nearer to the intention. Most late $\mathbf{1 9}^{\text {th }}$ - and early $\mathbf{2 0}^{\text {th }}-$ century composers wrote symphonic poems though they did not always so describe them, e.g. Delius's In a Summer Garden. Elgar used designation 'concert-ov' for what are in effect 3 symphonic poems (Froissart, Cockaine, In the South) and he called Falstaff a 'symphonic study'. Later $\mathbf{2 0}^{\text {th }}$ - century composers have shown less interest in the form, but it still survives in such works as Birtwistle's The Triumph of Time (1972) and Tippett's The Rose Lake (1991-3). (KENNEDY et all., 2013:831)

The interrelated functions of program and music form in symphonic poems still puzzle many scholars, and lead to various schools of thought. Regarding relationship between program and form in Liszt's symphonic poems, according to John, Saffle (1997:5), four main schools of thought have emerged. The first school (which included some of Liszt's earliest critics) maintains that there is no relationship between program and music, and that the music itself is without meaningful formal structure. The second school maintains 
that symphonic forms are totally governed by extramusical, programmatic elements, while the third claims that they incorporate some version of sonata form. Finally, the fourth school maintains that each symphonic poem is unique composition and that, although there may be similarities between some of these works, relationships between program and music within them gives rise to no single structural paradigm.

\section{Methodology}

In this work methodology is based on interview and analytical approach, which complement and inform the mixture of historical musicology and analysis that governs this article as a whole. The aim of the interview and analysis is to offer a multidimensional view of the whole work, which includes the form and performance context.

With the intention of gathering the information relevant for the national and international music historiography, we used the so-called soft interview or the research interview, as a method of scientific/musicological research, the type of "interview that deals with experiences which are permanently incorporated in the subject's personality, and the general incentive is sufficient to induce them to express their attitude and give lots of specific information” (MARINKOVIĆ, 2012:7). Through the research interview the aim was to get to know and acknowledge the way of thinking and the ideas of the creators of works during his life, so that his ideas would not be in the future incorrectly interpreted, and to with ease follow and understand the musical turnovers and contrasts of the "Ratna poema" symphonic poem.

\section{Instrumentation and the first performance of "Ratna poema"}

Although written in 1999, the premiere performance of "Ratna poema" or "The War Poem" by the pianist Slađana Marić and The Grand Tamburitza Orchestra of RadioTelevision of Vojvodina ${ }^{4}$, led by the composer and conductor Ferenc Kovač, was held on $24^{\text {th }}$ of May, 2011, celebrating the forty years of artistic work of the composer, in the concert hall "Studio M" of The Public Broadcasting Service of Vojvodina Radio-Television of Vojvodina, in Novi Sad (Vojvodina, Serbia). That evening the audience in the concert had the opportunity to experience the enormous possibilities of musical expression of tamburitza orchestra and the grand piano. The full performance (17:22 minutes) can be previewed on the official channel of the pianist Slađana Marić and the composer Ferenc Kovač on You Tube (MARIĆ, 2014; KOVAČ, 2011). As the composer stated, the "War Poem" music piece was dedicated to "all those who defended the country from aggression and who have died in this fight", the victims of the NATO attack and bombing of Serbia (KOVAČ, 1999/2011).

The aim of the following interview was to get to know and acknowledge the way of thinking and the ideas of the composer Ferenc Kovač during his life, to with ease follow and understand the musical turnovers and contrasts in the symphonic poem "Ratna poema" / "The War Poem". The main questions from the interview were the story about the birth of the music piece „The War Poem“, the main ideas behind the choice of instruments, and if encountered any difficulties when changing the type of orchestra, to which composer replied the following: 
"As I mentioned, the composition was originally written for the piano and symphony orchestra. Later I replaced the symphonic orchestra part with the tamburitza orchestra as I knew it would also sound good together with the piano, even better."... "No, not at all. There aren't any difficulties there, because, in terms of sound, frequencies of the tamburitza orchestra are not far away from the symphonic. They don't have, for example, tubas, timpanies or piatti, instruments that can make a huge sound pressure. That is why tamburitza orchestras are a little bit softer in sound then the symphonic.” (MARIĆ, 2015. Interview)

In examining the role and relationship of the piano in the arrangment, from the composers point of view "the piano is treated as a solistic instrument accompanied by the orchestra" and the role model for the pianistic line was not Liszt, as we suggested, because of the Hungarian origin of the composer, but Chopin.

We were particularly interested in the the story or the narrative behind the music themes in the War Poem, as it was not given in a program or discussed before.

"Briefly, the poem is in three-part form. The first theme, as I felt it, in the poem is actually - shock... Shock we all have experienced when the first bomb hit! The second, is rebelion when we all went out into the streets, to squares and bridges to show our courage and to end this situation. The will of the people to stand up and protect theirselves and others,...presents their revolt to the aggression and attacks from the sky. Then,... tranquillity, the period of reconciliation, that is the third theme,...when the peace was signed in Kumanovo and NATO stopped destroying and bombing the Serbian territory." (MARIĆ, 2015. Interview)

From the conversation we can say that the composer developed a certain personal model of writing symphonic poems in terms of macro structure, where he builds the piece (music themes) according to the main events or parts of the story that the music represents, for example in the "War Poem" he distinguishes three main themes: $1^{\text {st }}$ shock $-2^{\text {nd }}$ rebelion $-3^{\text {rd }}$ peace, and in "Hiroshima-Nagasaki" only two themes $\left(1^{\text {st }}\right.$ Hiroshima and $2^{\text {nd }}$ Nagasaki), as stated by the composer:

"From those performed or recorded, the interesting symphonic pieces are the symphonic pictures titled Vuchedol's Dove, where every movement is different. It was written after the book by Duško Trifunović where a dove was flying high above and watching the events bellow with the river Danube as a narrator,...watching all the historical events and people who were there from the time of The Avars, Celts, Suleiman the Magnificent, Maria Theresa, and others. From the symphonic poems, I have dedicated a symphonic poem titled Hiroshima-Nagasaki to the Japanese people, 50 years after the event. In that music piece there are two themes, the first is Hiroshima and the second, Nagasaki. The development follows the flow of time before, during and after the event, slowly calming the situation and the reconstruction of the country." (MARIĆ, 2015. Interview)

In summary, from the biographical and information gathered through the interview, we can say that Ferenc Kovač is a composer of absolute and "programme" music, although that difference today is not important and polarised as it was centuries ago. In the field of classical music F. Kovač works are the following:

- Quintet Rondo Caprice (for flute, violin, faggot, violoncello and piano)

- Quartet Scerco (for flute, violin, faggot and piano)

- Symphonic pictures: Vučedols Dove (Vučedolska golubica - simfonijske slike, 1980s)

- Symfonic poems (orcherstral pieces): 
- Contours of Irregular Rhythms (Konture nepravilnih ritmova);

- Hiroshima-Nagasaki (1995);

- Happy Birthday - (Srećan rođendan - Srećno u 21.vek) (1997-8);

- Symphonic poem for piano and orchestra

- War Poem (Ratna poema) for piano and orchestra (1999);

- War Poem (Ratna poema) arrangement for piano and tamburitza orchestra (2011)

- Symphonic fantasy:

- Diana (1997);

- Romanian impressions (Rumunske impresije, 2015) - symphonic fantasy with two themes in Romanian stile.

- Symphony:

- Symphony of Vojvodina (Vojvođanska simfonija) - unfinished.

- Choral work:

- Millenium - choral piece for female choir (three voices) and piano (2000);

- Millenium - arrangement for violin and tamburitza orchestra (2008).

- Millenium - arrangement for violin and symphonic orchestra (2015).

- Diana - symphonic fantasy, arrangement for piano (1997).

\section{Analysis of "Ratna poema" arrangement for the piano and tamburitza orchestra}

The piano has been, and continues to be one of the most crucial instruments in the history of western classical music, jazz and popular music. According to Eberst (1997:24) at the beginning of the $20^{\text {th }}$ century in Novi Sad a new, "light" form of music appeared in Novi Sad. This was something between the tamburitza and the piano, between folklore and salons. We can now say that at the beginning of the $21^{\text {st }}$ century in Novi Sad, "The War Poem" for piano and tamburitza orchestra, represents a new form combining the piano and tamburitza orchestra, moving from the divide of being "something between the tamburitza and the piano, between folklore and salons", establishing its place in the field of contemporary classical music.

In relation to the past, there are examples of symphonic poems that are a genre combination of piano concerto and symphonic poem, for example, George Gershwin, An American in Paris, 1928 symphonic poem. To some this type of symphonic poem may be described as a simfonised concert where the soloist and orchestra are equal, and the shape is constructed in the symphonic manner (this is reflected in the type of thematizm, equality of both partners in exposition and development of motive materials, the increased importance of the development part, etc.), but with a tendency towards compressing the symphonic cycle in a single-movement. (Examples of such concerts are Piano Concerto in A minor by Schumann, Piano Concertos in E flat major and A major by Liszt; Piano Concerto in $D$ minor and $B$ major by Brahms).

Although Kovač gave his symphonic poems descriptive titles, his music is strong in emotions as well. The composer follows the notion that the outside explanations of music are not necessary. The aesthetic base of the music piece can be found in itself, without additional detailed non-musical programme. Throughout history many composers tried to bring their music and ideas closer to the audience by giving a programme. Later, they had realised that this had an opposite or different affect or results on the audience, and they usually changed or withdrawn the programme presented. 
As presented above, Kovač wrote many symphonic poems of about ten to thirty minutes duration. Most of these poems are inspired by historical event or human feelings (Contours of Irregular Rhythms, Diana, Hiroshima-Nagasaki, War Poem, and Happy Birthday, etc.). Some were even written during important historical events, such as the Hiroshima - Nagasaki, after the 50 years from the attack and the War Poem, during the bombing of Serbia in 1999 (many examples in music history of such acts are known: Chopin's Revolutionary Etude, Beethoven's Eroica, Verdi's “Va pensiero" chorus of Hebrew slaves from opera Nabucco, etc.).

This is perhaps the place to emphasise that we agree with Steven Vande Moortele who believes that "the notion of musical narrative is a deeply problematic one, not in the last place because of the semantic indeterminacy of music". He states the position of a narrative within music in an unmetaphorical sense is, strictly speaking, impossible. "A narrative can, however, be constructed by the listener and projected onto the music. In this act of constructing and projecting a narrative, the reader may be guided not only by the music itself, but also and even more by a program and a title, as well as by certain generic conventions" (MOORTELE, 2006:74).

Thus, we believe that in "The War Poem" composer Kovač uses his music to create a general mood or atmosphere of the war in 1999, without any illustrative narrative or describing something literally in the performance program accept the title and dedication in the music score. Thus, this music may evoke the memory of some listeners of the time when many civilians died in bombing of all three bridges in Novi Sad and the The Public Broadcasting Service of Novi Sad building, of people living and working in that period of sorrow and fear, running to shelters, not knowing if the next bombs will fall on their heads, believing in better tomorrow and wishing for piece and happiness that a new morning may bring. For those who have not experienced or heard about those events, the music of "The War Poem" may or may not inspire them to imagine or consider scenes, images, moods and dramatic associations in that piece of music, as this orchestral work with a solo piano is a unique combination of memorable tunes, good construction, and vivid orchestration.

The three aesthetic goals reached with this poem are: (1) it relates music to outside sources, (2) there are tree themes combined into a single principal section, and (3) it especially elevated the level of classical music pieces primarily composed for tamburitza orchestra on the international level.

In turns of musical structure, "Ratna poema” or in English “The War Poem” for piano and tamburitza orchestra by Ferenc Kovač, is following a non-strict episodic pattern presentation and development of three basic musical themes, visible in unpublished score by KOVAČ (FINALE, 2011). After being contrasted in development, shortened themes were later restated and shuffled into new and unexpected patterns of order in a continual process of creative experimentation by the composer. In this piece special emphasis was given on the thematic and tonal contrasts.

After the orchestral introduction ${ }^{5}$ (Example 1a.), starting with Prim I and II playing a motive from the first theme in high register (bar 1), on which the Basprim I, and then Basprim II and E-Basprim replay in lower register (Example 1b. bars 2-5), adding more layers with piano broken-chord triplets (bar 6-11) and low and steady bas line in unison with the line of the Bas moving to a peak, then returning down (bar 6-11), making one more wave (bar 12-15) leading to the "destiny question" chords in forte (16-18). 


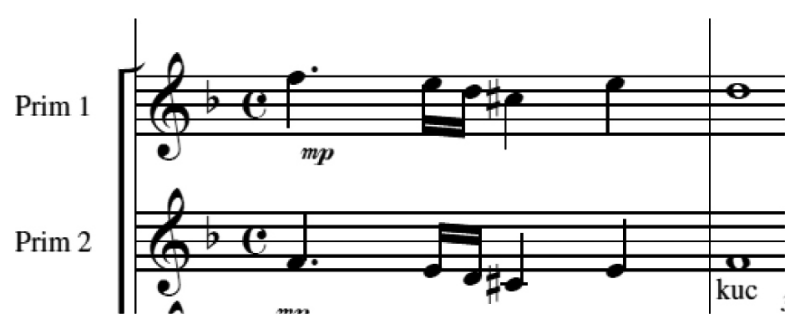

Example 1.a: Score: Introduction part (bar 1).

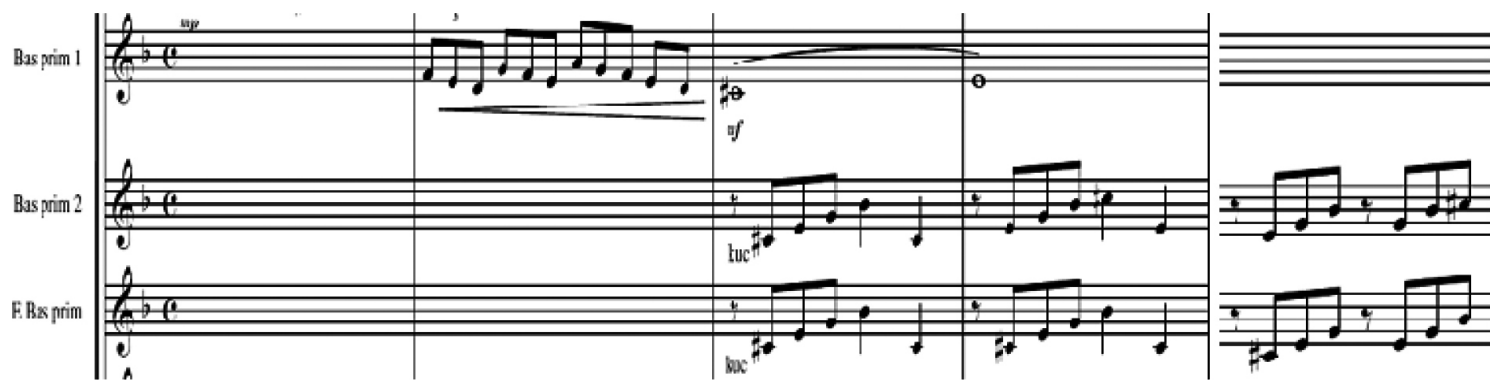

Example 1b: Score: Introduction part (bar 1-5).

In the interview with Ferenc Kovač we have discovered that the first theme, starting with the D-minor fortissimo chord of piano and orchestra (Example 2, in red), should represent "the shock experienced by all the people living in, and out of, the country when the first bomb hit (people at work, children in schools or at playgrounds, etc.)", while the second theme, in D - major, 12/8 measure, strong in character, shown by syncopated rhythm (Example 3) represents "the will of the people to stand up and protect their selves and others or presents their revolt to the aggression and attacks from the sky" (Example 3. Piano line and tutti).

However, it is not all about virtuosity, and the War Poem presents a work not designed merely to show off a pianist's technique. Piano may be seen as the main leader in bringing the longing melodies of tortuous beauty, but the orchestra is not left behind as a pure accompaniment, it also has a role in presenting widely spanning melodic arcs, making a dialogue with the piano. In general, the piano line changes its level of transparency and lightness of sound through the themes, by thinning-out of density in some parts across the whole range of keyboard, and by sensitivity to nuances of dynamics and articulation. The material in the left hand is not as technically difficult as in some of the right-hand parts (parallel triads and sixths, long melodies in octaves or parallel chord movement), but it overall, it is important to voice it well, and maintain a strictly steady rhythm. 


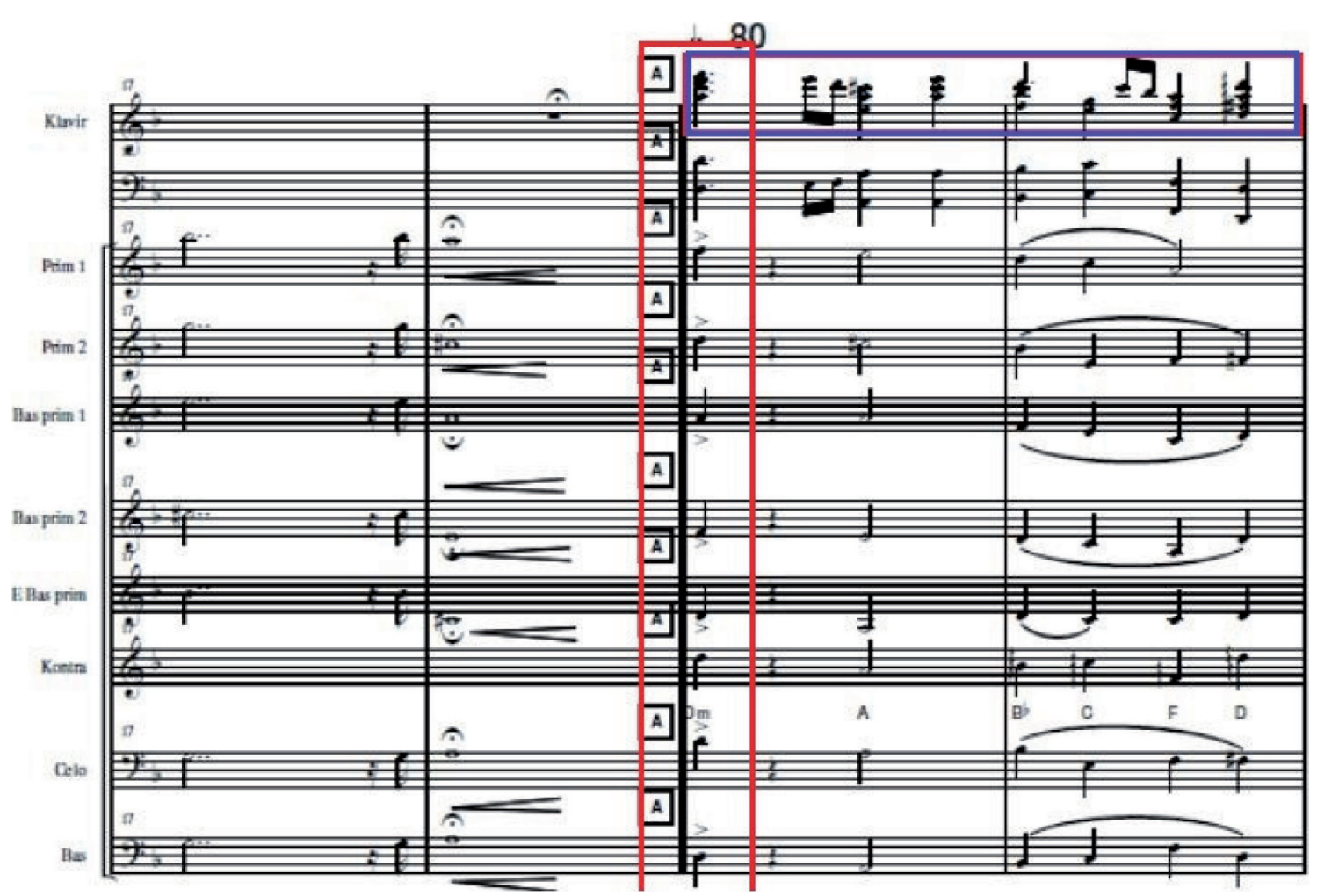

Example 2: The first theme (bar 19).

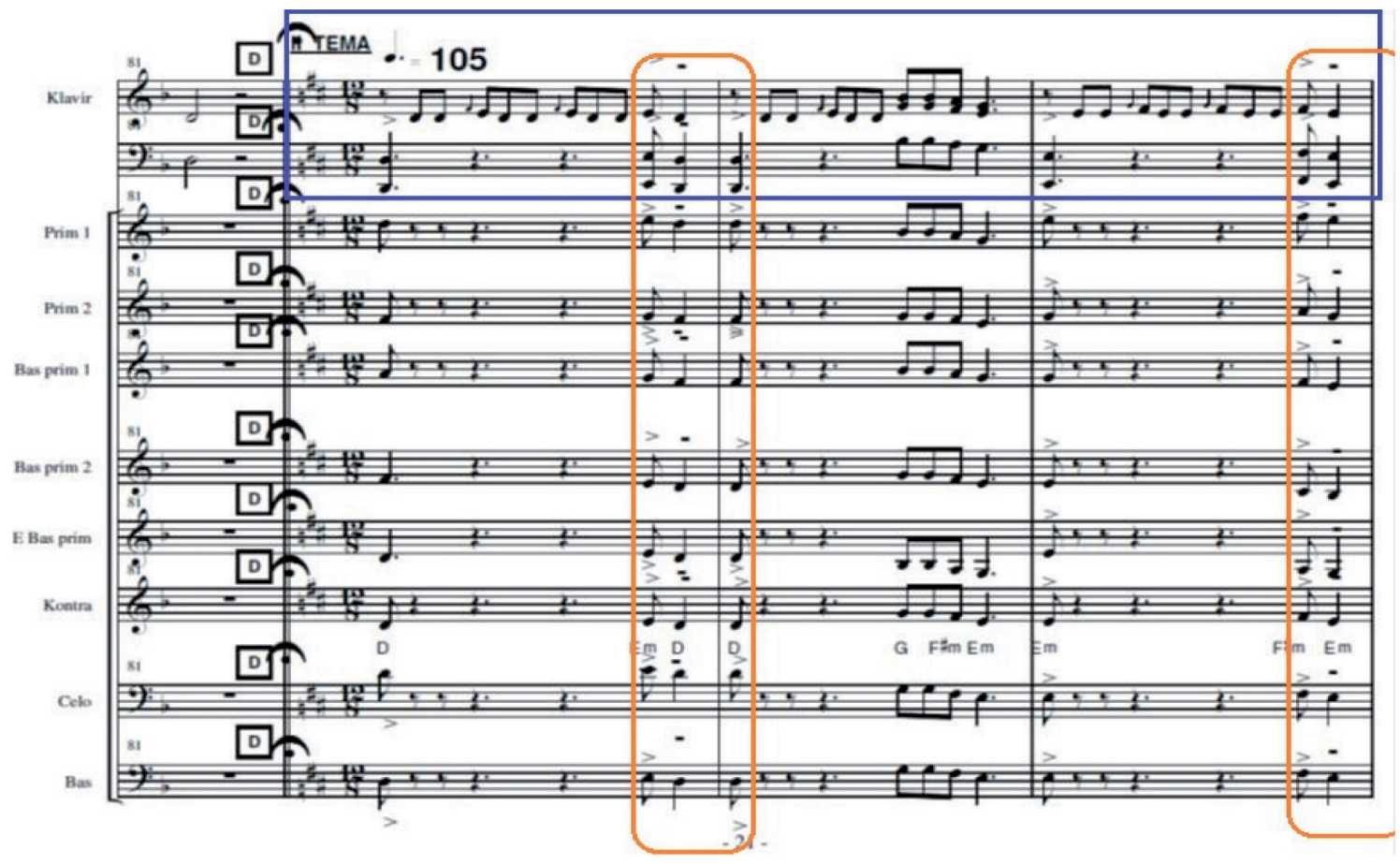

Example 3: The second theme (piano line and tutti).

The third theme in G- major and $3 / 4$ waltz time (Example 4), according to Kovač "represents the period of reconciliation, when peace was signed in Kumanovo and NATO stopped destroying and bombing the Serbian territory" (INTERVIEW, 2015). 


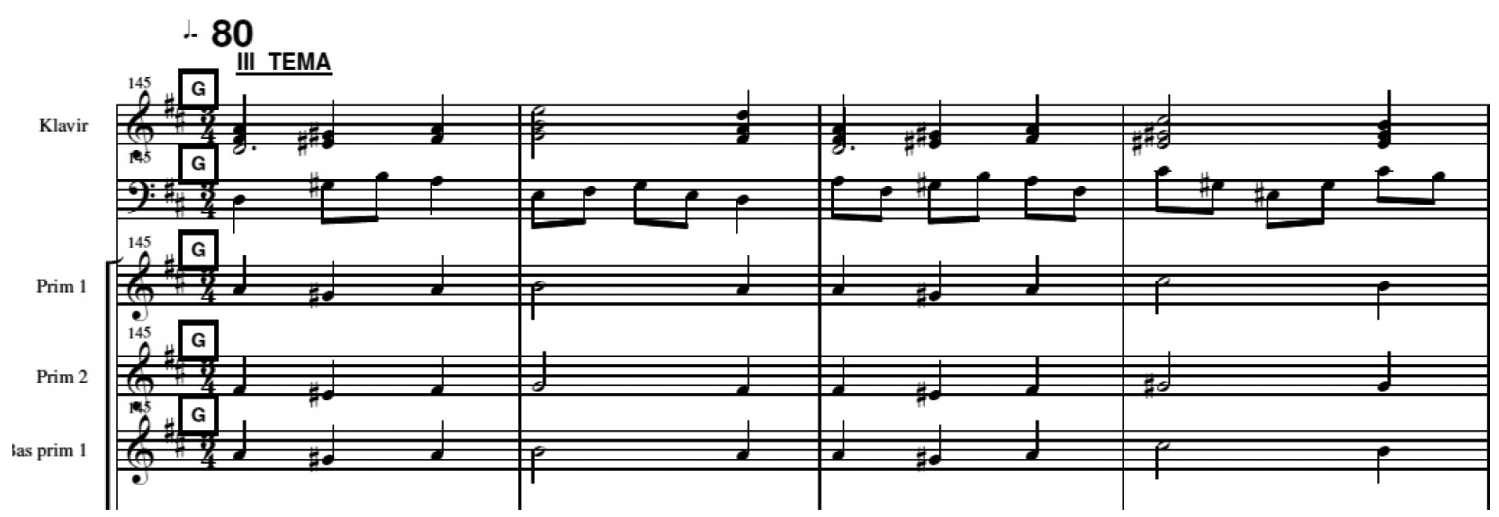

Example 4: The third theme (piano line) extract.

In the following example, the orchestra leading with the second theme for three bars (Example 5, bar 314 -316) is suddenly changing the mood (Example 6, bar 317- 320), firstly, to the third theme augmented in values and with a beginning slightly moderated, but easily recognised from bar 325 to 327 (Example 7), then, again interrupted by the second theme motive in bar 328.

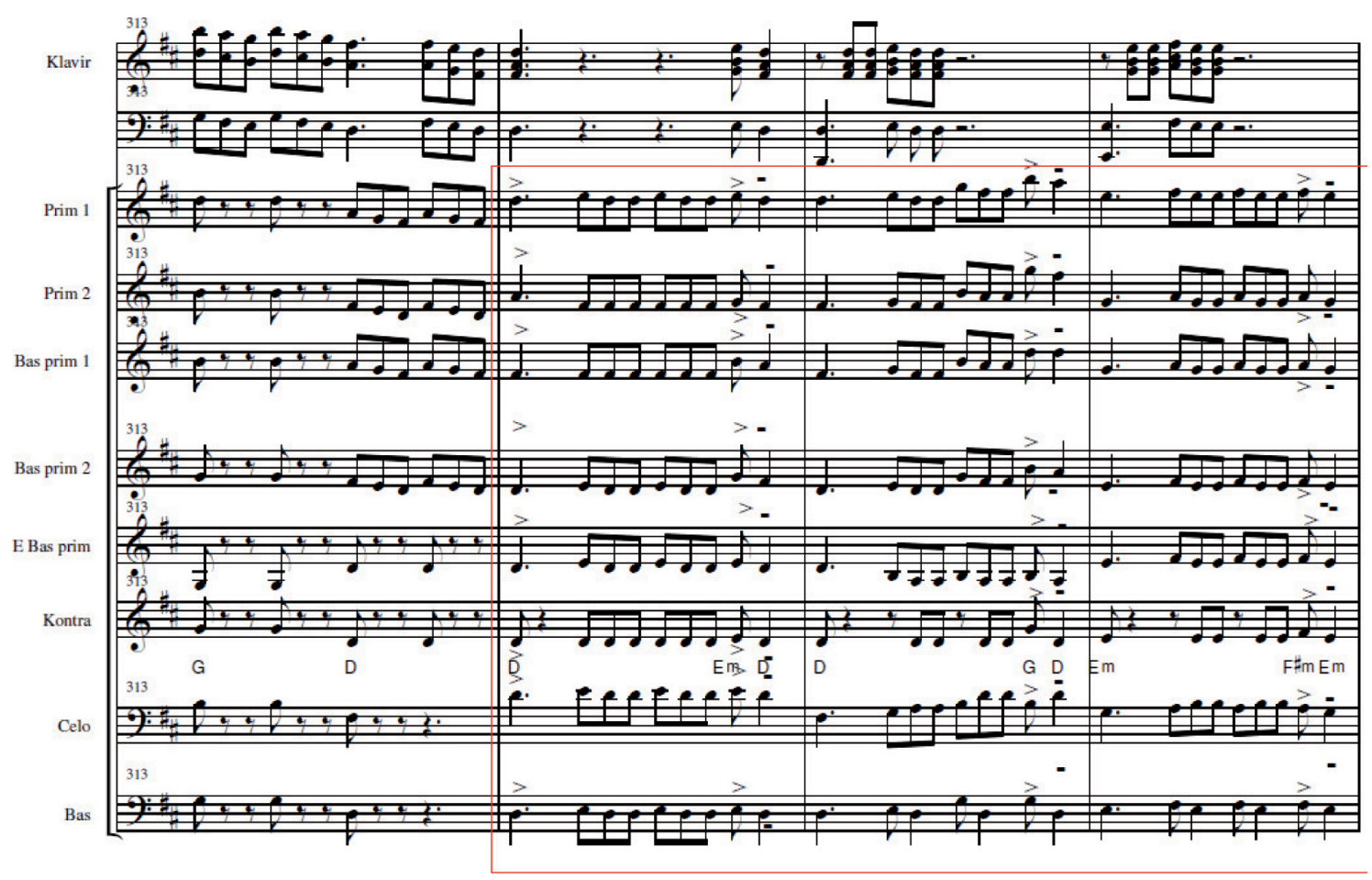

Example 5: The second theme in the orchestral part. 


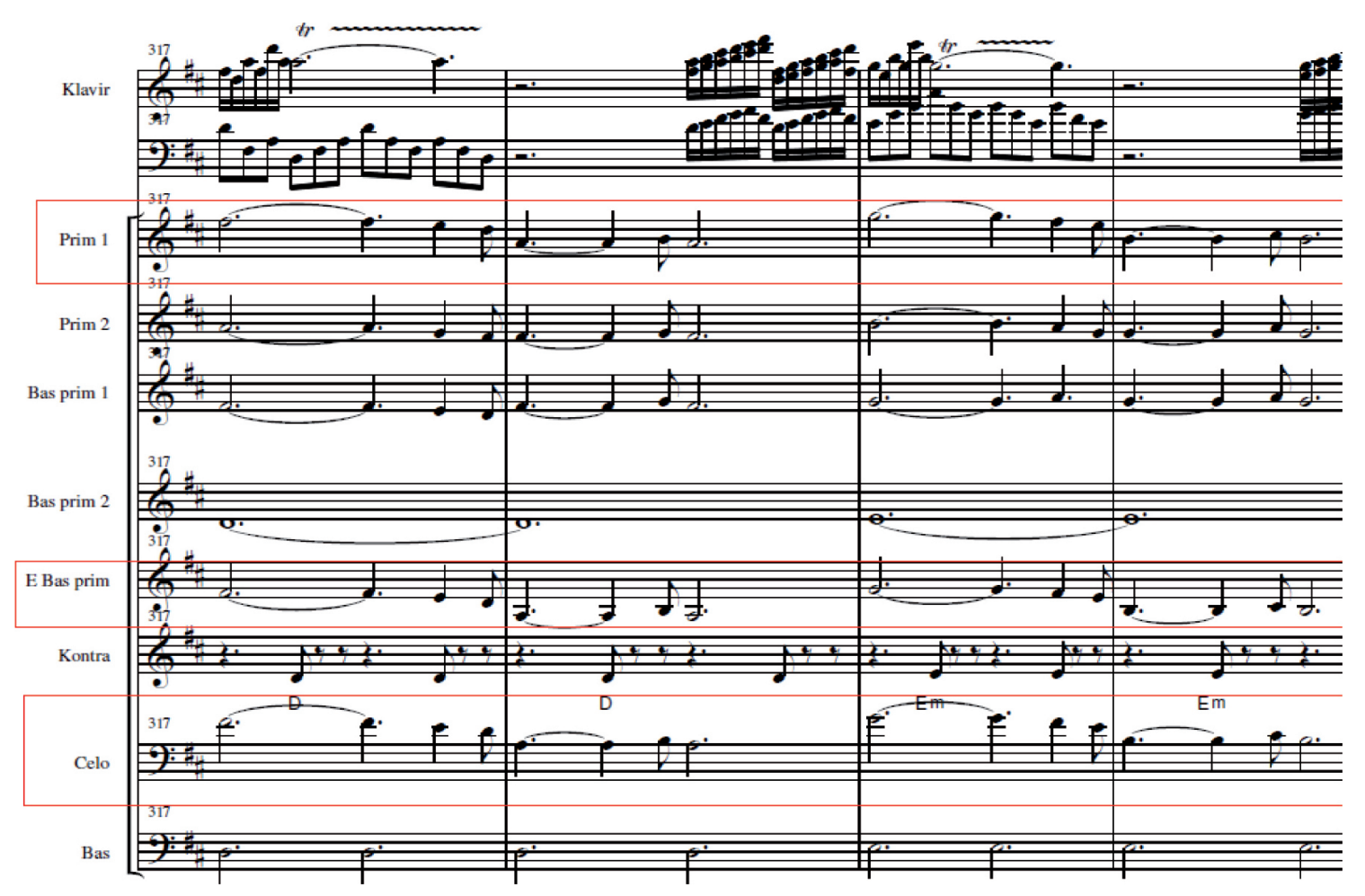

Example 6: Third theme augmentation and modification.

The augmented and modified theme shown in the picture (Example 6), culminating with the highest note and tonal peak by Prim - a3 (a2 written), shown in Example 7, in our opinion may trigger memories of tranquillity and happiness of those mornings awaking "alive" and enjoying those ordinary family and friends moments before the sound of sirens is heard again, announcing the approaching horrors and the red sky filled with smoke and dust.

Although its appearance was initiated by the events the composer experienced in his homeland, the music is not used as a vehicle for expressing 'nationalism' in music in any sense. The War Poem does not follow a detailed narrative programme, it rather paints a more general picture in the mind's eye by pulling the features of a specific scenes and atmosphere given with the title of the piece and the dedication.

This symphonic poem is entirely fresh in its approach to structure. Essentially, the novelty is not in the treatment of form, more in the approach to orchestral sound, where instead of a symphony orchestra the composer used the tamburitza orchestra, where all the melodic instruments have the equal importance in introducing the thematic material towards the relationship with the piano role (Example 8). 


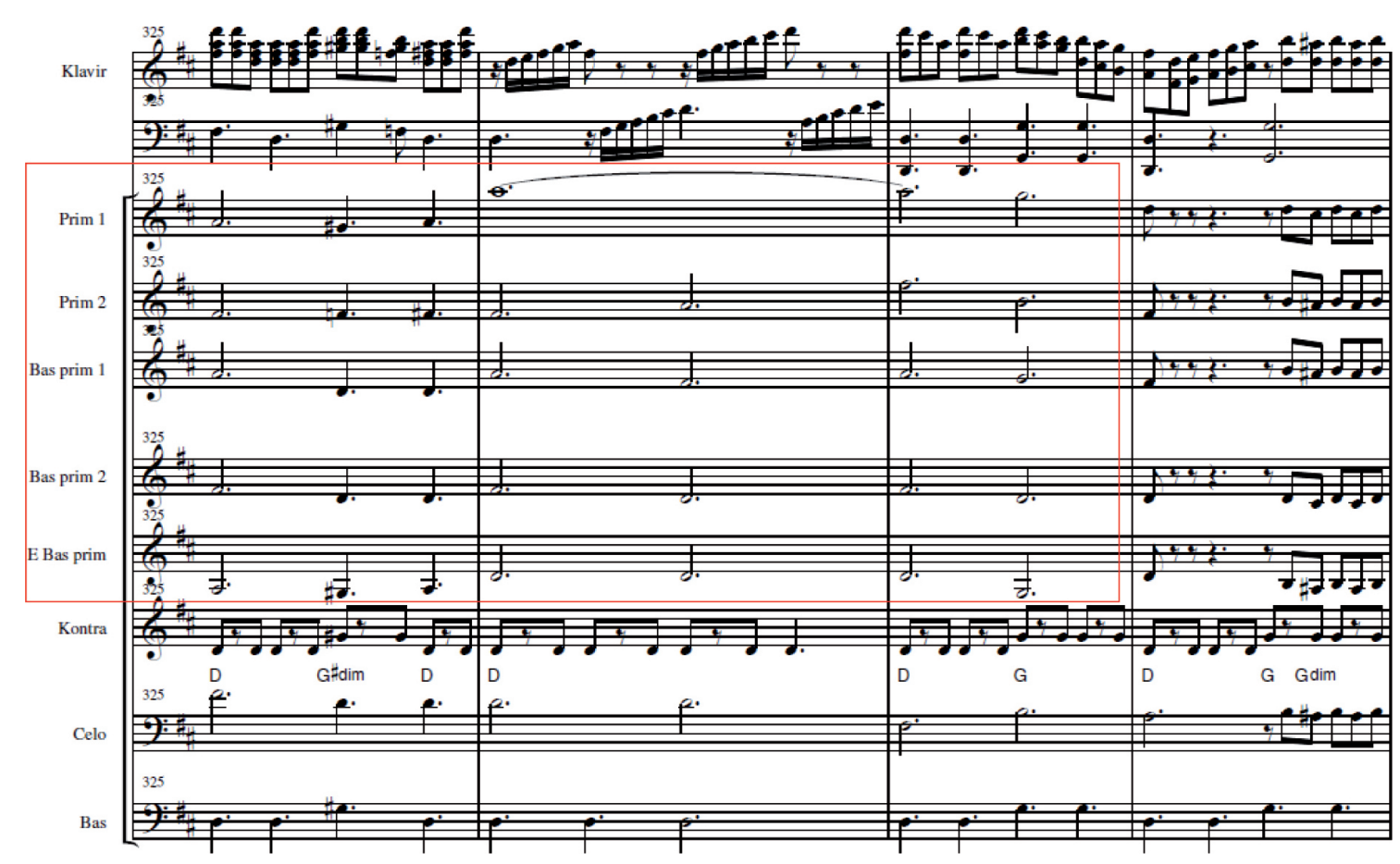

Example 7: Culmination and tonal peak (bar 326).

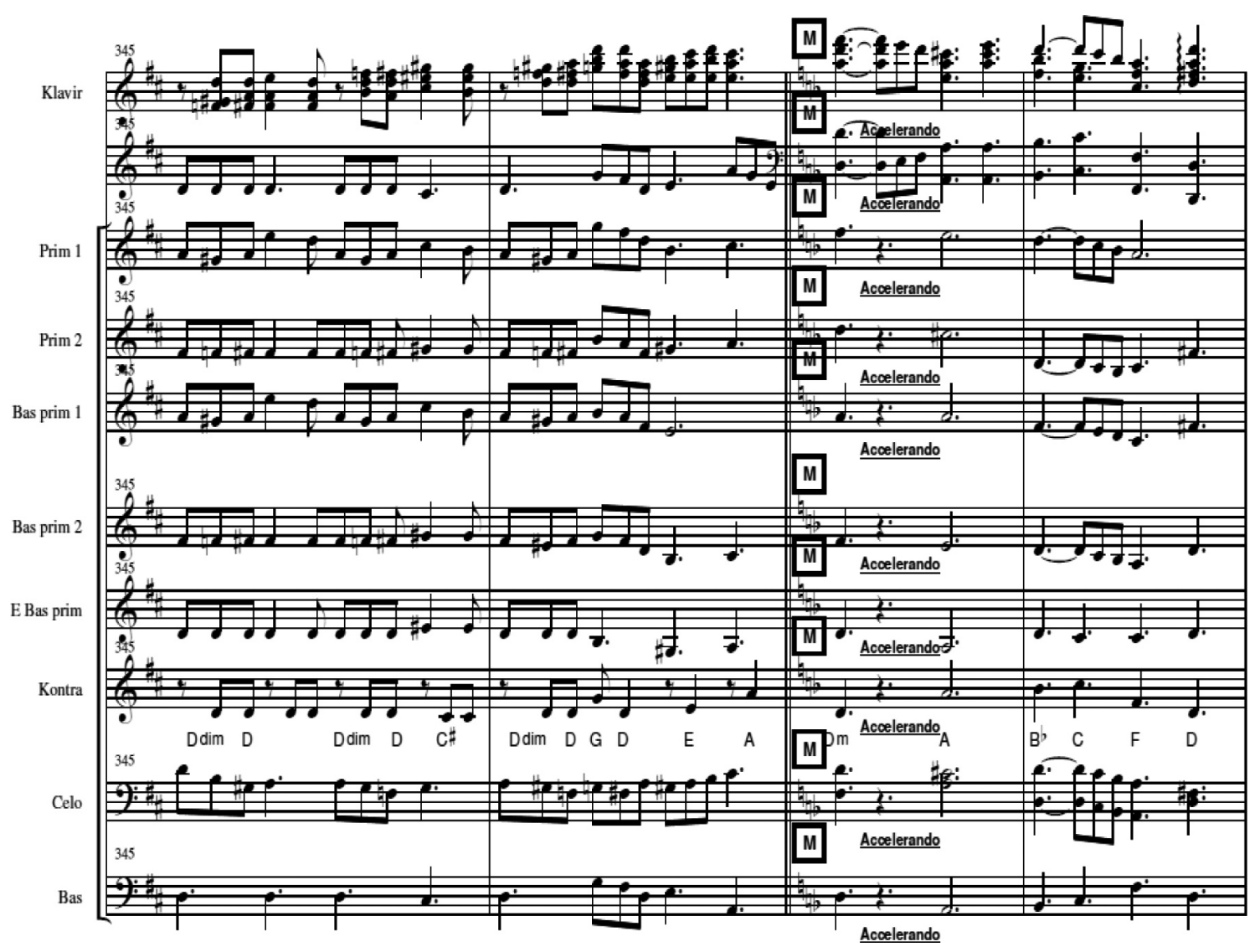

Example 8: Relationship of piano and orchestra.

In the following part (Example 9) we presented a detailed structural and harmonic analysis of this music piece regarding all the necessary information, such as position of themes, motive work, major changes in tonality, and tempo and time signatures. 


\begin{tabular}{|c|c|c|c|c|c|c|c|c|c|c|}
\hline Bar number & $1-18$ & $19-37$ & $38-43$ & $44-59$ & $60-65$ & $66-71$ & $72-81$ & $82-88$ & $89-110$ & 111-117 \\
\hline Letter mark & Introduction & $A$ & $\mathrm{~A} 1$ & $B$ & B1 & B2 & C & $\mathrm{D}$ & D1 & $E$ \\
\hline Theme & $\begin{array}{l}\text { (motive } \\
\text { work) }\end{array}$ & Theme I & $\begin{array}{l}\text { Motive } \\
\text { work }\end{array}$ & Theme I & $\begin{array}{l}\text { Motive } \\
\text { work }\end{array}$ & $\begin{array}{l}\text { Motive } \\
\text { work }\end{array}$ & Theme I & Th.- II & $\begin{array}{l}\text { Motive } \\
\text { work }\end{array}$ & $\mathrm{mw}$ \\
\hline $\begin{array}{c}\text { Time } \\
\text { Signature }\end{array}$ & \multicolumn{7}{|c|}{$4 / 4,=75$} & \multicolumn{3}{|c|}{ 12/8, 105} \\
\hline Tonality & $\begin{array}{c}\mathrm{D} \mathrm{m} \\
(\mathrm{m}=\text { minor })\end{array}$ & $\mathrm{Dm}$ & $\mathrm{Dm}$ & $\mathrm{Dm}$ & $\mathrm{Dm}$ & D m & $\mathrm{Dm}$ & D-major & $\begin{array}{l}\text { Bm, Em, } \\
\text { D, Bm, D }\end{array}$ & D \\
\hline Bar number & 118-122 & $123-128$ & $129-134$ & $135-140$ & $141-144$ & $145-152$ & $153-160$ & $161-168$ & $169-176$ & 177-184 \\
\hline Letter mark & E1 & E2 & E3 & $F$ & F1 & $G$ & G1 & G2 & G3 & $\mathrm{H}$ \\
\hline Theme & $\mathrm{mw}$ & $\mathrm{mw}$ & $\mathrm{mw}$ & $\mathrm{mw}$ & $\mathrm{mw}$ & Theme III & $\mathrm{mw}$ & $\mathrm{mw}$ & $\mathrm{mw}$ & $\mathrm{mw}$ \\
\hline $\begin{array}{c}\text { Time } \\
\text { Signature }\end{array}$ & \multicolumn{4}{|c|}{ 12/8, 105} & $\begin{array}{c}6 / 8,3 / 8 \\
6 / 4\end{array}$ & \multicolumn{5}{|c|}{$3 / 4$} \\
\hline Tonality & $\mathrm{D}$ & $\mathrm{D}$ & $D$ & $\mathrm{D}$ & $\mathrm{D}$ & $\mathrm{D}$ (major) & $E m-D$ & $\mathrm{D}$ & Em - D & A \\
\hline Bar number & $185-192$ & 193-212 & $213-235$ & 236- & 254- & $263-$ & 267- & 273- & $314-$ & $347-375$ \\
\hline Letter mark & $\mathrm{H} 1$ & $\mathrm{H} 2$ & I & \multicolumn{4}{|c|}{1} & \multicolumn{2}{|c|}{4} & $M$ \\
\hline Theme & $\mathrm{mw}$ & $\mathrm{mw}$ & $\begin{array}{c}\text { Reminis- } \\
\text { cence of } \\
\text { Theme II } \\
\text { (motive) } \\
\text { * piano }\end{array}$ & $\begin{array}{c}\text { Reminis- } \\
\text { cence of } \\
\text { Theme I } \\
\text { (motive) } \\
\text { *orchestra }\end{array}$ & $\begin{array}{l}\text { Remin. of } \\
\text { Theme I } \\
\text { motive } \\
\text { *orch. }\end{array}$ & $\begin{array}{c}\text { Remin. of } \\
\text { Theme II } \\
\text { motive } \\
\text { *piano }\end{array}$ & $\begin{array}{c}\text { Remin. of } \\
\text { Theme III } \\
\text { motive } \\
\text { *piano }\end{array}$ & $\begin{array}{c}\mathrm{T}-\mathrm{II} \\
\text { material } \\
\text { *piano }\end{array}$ & $\begin{array}{l}\text { T- II } \\
\text { *orch. }\end{array}$ & Coda \\
\hline $\begin{array}{c}\text { Time } \\
\text { Signature }\end{array}$ & \multicolumn{2}{|c|}{$3 / 4$} & $\begin{array}{l}3 / 4, \\
=200\end{array}$ & \multicolumn{4}{|c|}{$4 / 4$} & \multicolumn{3}{|c|}{$12 / 8$} \\
\hline Tonality & A & A & A-major & $D-m$ & & $\mathrm{Dm}-\mathrm{D}$ & $F-D m$ & $D$ & $\mathrm{D}$ & Dm,D. \\
\hline
\end{tabular}

Example 9: The structural and harmonic analysis of the piece "The War Poem".

\section{Final Remarks}

The aim of this work to present, a unique music piece in contemporary piano and tamburitza orchestra repertoire in the field of composed classical music, the symphonic poem arrangement for piano and tamburitza orchestra titled "Ratna Poema" or "The War Poem" by Ferenc Kovač. With the intention of gathering the information relevant for the national and international music historiography, acknowledge the way of thinking and the ideas of the creators of works during his life, we used the so-called soft interview or the research interview, as a method of scientific/musicological research.

In general, this orchestral work with a solo piano, is a unique combination of memorable tunes, good construction, and vivid orchestration. The analytical interpretations offered in this paper may be the first guidance for future interpretation or performance of the piece. This analysis was not intended to impede each individual listener's construction of this music piece, nor to be the only one and definitive interpretation. In conclusion, further examinations of early versions of the other symphonic poems, as well as other contemporary, would contribute still more to our understanding of this genre and its development. The comparative analysis of all symphonic poems/pictures/fantasies of the composer and other new symphonic poems on a global level may be done in future research.

\section{Notas}

1 Note: Letters of Serbian language my be replaced as following: $\check{s}$ with $s$ or $s h$, $\check{c}$ with $c$ or $c h, c ́$ with, $c, \check{z}$ with $z$, $d \check{z}$ with $d z$, đ with $d$ (or $d j$ ).

2 Ferenc Kovač (Kovács, 1948), composer, arranger, conductor, music producer and editor. Born in Debeljača in 1948. After finishing the Secondary Music school "Mokranjac" in Belgrade, both in music theory and double bass, Ferenc enrolled and graduated at the Faculty of Musical Arts in Belgrade. He worked in Radio Novi Sad 
from 1969-2011 when he retired after more than 40 years of artistic work. His positions developed from the bass and keyboard player of the Dance Orchestra, to producer of the same orchestra up to year 2002, and The Grand Tamburitza Orchestra of Radio-Television of Vojvodina conductor (from 2007-2011). For twenty years he has been the music editor of "Zmajeve dečije igre" festival for children in Novi Sad, and for twenty three years the music editor of The Festival of Joy, Education and Culture of Children "Raspustilište" in Novi Sad. He was also the music editor of the redaction program for children of Radio-Television of Vojvodina. Kovač wrote pieces in light orchestral and jazz style, musical dramas, more that 200 songs for television show "Happy Windmill” "Vesela vetrenjača"), music for Hungarian Theatre "Újvidéki szinház" and music for the first cabare for children in Europe for the Theatre „Pozorište mladih” titled: “Tell lies from the bag” (Laži kaži iz džaka”). In his opus he dedicated many attention to the songs for children with choir. For the children's choir "Zvončići” (Jingle Bells) from Novi Sad, and their soloists, he composed and published many CD albums. For his compositions, songs, arrangements he had won over 40 awards from institutions and on national and international festivals of music for children (Bolognia, Bari - Italy, Onesti - Romania, Bankya - Bulgary, Malta). Some of these international awards include: Festival Ti Amo 2006 and UNICEFF award for PEACE and previous work in the field of children's music; Second award for composition and arrangement at Ti Amo 2007, 2008; Golden Badge of the town Onesti in Romania, 2007, etc. Ferenc Kovač also received more then 30 recognitions, letters of thanks, plaques and diplomas for his compositional work and work with talented children. He was a jury member in many festivals in the country and abroad. His songs for children are published in the following books: The lyrics of Dragutin Beg with the music notation of Ferenc Kovač (original title: Knjiga sa stihovima Dragutina Bega i notnim zapisom Ferenca Kovača) - 15 compositions, Public Library of Vukovar, 1997; Jingle Bells singing songs by Ferenc Kovač (Zvončići pevaju pesme Ferenca Kovača) - 18 compositions, Published by Academic Publishing House SCI (Akademska izdavačka kuća SCI), 1998; Songs on the lyrics of Dragutin Beg 'On the North Pole' (Na severnom polu) - 17 compositions, Published by SPD Papirus Bačka Palanka, Serbia, 2003.

3 Because of its longtime presence and development in Vojvodina (Northern region of Serbian), Tamburitza (Serbian: Tamburica)/Tambura is recognised as a national folk instrument, specific to the people living in that part of the country, and also a classical music instrument for performing pieces of all periods. It can be studied as an instrument subject in both primary music school (six years of study) and secondary music school (four years of study) in Novi Sad, Subotica or Sremska Mitrovica (Vojvodina, Serbia). Tambura is a fretted, lute like, stringed instrument that comes in five basic sizes and shapes. The oval shaped 'Prim' is the smallest of the five and plays the melody and harmony in the highest octaves (strings: $\mathrm{e}^{2}, \mathrm{~b}^{1}, \mathrm{f} \#^{1}, \mathrm{c} \#^{1}$; first string is doubled and it sounds an octave higher than written). The tenor guitar shaped 'Basprim' (strings: $\mathrm{a}^{1}, \mathrm{e}^{1}$, b, f\#; sounds as written) is the next largest and plays the melody and harmony in the mid range octaves. The guitar shaped 'Cello' or Serbian 'Čelo' (strings: A, E, B1, F\#1; sounds as written) is approximately the size of a folk guitar and plays counter melody in the lower octaves, much like a cello in a symphony. The 'Kontra' (strings: $\mathrm{e}^{1}$, b, g\#, e) is similar in size and shape of the Čelo and plays only chords for counter rhythm. The double bass shaped Counterbass or Bass (Serbian: 'Kontrabas' or 'Bas', strings: A-E-B1-F\#1; sounds an octave lower then written) plays the bass part of the rhythm in the lowest octaves. It is very important to note that, like the other instruments in the tamburitza family, the Bas is fretted, has wire strings, and is played with a plectrum or a pick.

4 The Grand Tamburitza Orchestra of Radio-Television of Vojvodina, was founded in 1949 by the name Tamburitza Orchestra of Radio Television Novi Sad. Repertoire included songs and dances of all Yugoslav people and nationalities as well as compositions of popular and classical music. Performed at many festivals and places nationally as well as internationally, at the Paris "Olympia", the Film festival in Cannes, in many places in Hungary, in Vienna, Modena, Amsterdam, Rotterdam, Sofia, Athens, Benghazi, Tripoli, etc. Former conductors were Sava Vukosavljev and Zoran Mulić (EBERST, 1997: 159).

5 In terms of performance the composer in the score uses the term "kuc" to indicate that the notes are short, plucked with a pick. The performers should note that the term legato in all the scores for tamburitza indicates a melodic line where the players continuously plucks the chord up and down with a pick many times to make the tone last its full written duration (similar when string players play tremolo with a bow), while, if a player has notes tied with a dot above the last one, the dot represents the moment when the player stops the continual plucking. Pizzicato in the bas line is the same as playing a double bass, thus a player plucks a string with his finger. The instrument kontra has numbered chords beneath a base tone, played as guitar chords.

\section{References}

ASHKENAZY, Vladimir (Ed.) MUSICA: 1,000 Years of Classical Music. The Life and Times of the Great Composers. Australia: Millennium House Pty Ltd. 2010, ISBN 978-1-921209-49-9.

EBERST, Anton. Kovač Ferenc/Kovács Ferenc. In: Musical Breviary of Novi Sad. Novi Sad: Jeunesses Musicales of Novi Sad, 1997. p. 39,52.

EBERST, Anton. Musical Breviary of Novi Sad. Novi Sad: Jeunesses Musicales of Novi Sad, 1997.

GRIMLEY, Daniel M. The Cambridge Companion to Sibelius, Cambridge University Press, 2004. 
JOHNS, Keith T./SAFFLE, Michael (Ed.). The symphonic poems of Franz Liszt/ by Keith T. Johns; revised, edited, and introduced by Michael Saffle, Franz Liszt studies series, n. 3., Stuyvesant, NY: Pendragon Press, 1997.

KENNEDY, Michael; Rutherford-Johnson, Tim \& Kenned, Joyce. The Oxford Dictionary of Music, Oxford University Press, 2013.

KOVAČ, Ferenc. Ratna poema za klavir i tamburaški orkestar. Score/Partitura. Novi Sad: manuscript, 1999/2011.

KOVAČ, Ferenc. Ratna poema. (Premiere performance video). YouTube Channel - Ferenc Kovac: https://www.youtube.com/watch?v=CKixTjP43xQ. Posted on August 24, 2011. (Retrieved on June 30, 2015.)

KOVAČEVIĆ, Krešimir (Ed.). Simfonijska poema. Muzička enciklopedija, III knjiga, drugo dopunjeno izdanje, Zagreb: Jugoslovenski leksikografski zavod (Symphonic poem). Music encyclopedia, book III, second edition, Zagreb: Yugoslav Lexicographic Institute), 1977: 353.

LATHAM, Allison (ed.). Symphonic poem [tone-poem], In: SPENCER, Piers, The Oxford Companion to Music. Oxford and New York: Oxford University Press, 2002. ISBN 0-19-866212-2.

MARIĆ, Slađana. Ratna poema (Ferenc Kovac, kompozitor/dirigent) klavir - Slađana Marić. (Premiere performance video). YouTube Channel - Sladana Maric, Posted on October 6, 2014. https://www.youtube.com/watch?v=aWU_UJIUimY (Retrieved on June 30, 2015.)

MARIĆ, Slađana. Interview with Ferenc Kovač on June 14, 2015. Novi Sad. Recorded audio. Music studio SM. (unpublished).

MARINKOVIĆ, Sonja. Twenty years of the Composer Speaks section in the New Sound magazine: Interview as a method of musicological research, New Sound 40, II/2012, 81-97.

MOORTELE, Stevan V. Form, Program, and Deformation in Liszt's Hamlet. Tijdschrift voor Muziektheorie, Jaargang 11, 2, 71-82, 2006.

MOORTELE, Steven V. Beyond Sonata Deformation: Liszt's Symphonic Poem Tasso and the Concept of Two-Dimensional Sonata Form. Current Musicology, No. 86 (Fall 2008). City of New York: The Trustees of Columbia University, 41-62, 2008.

RANDEL, Don Michael. The Harvard Dictionary of Music, 4th edition, Harvard University Press Reference Library, 2003.

Slađana Marić (Eng. Sladana Maric) - music pedagogue, pianist, colouratura soprano and composer. She graduated music pedagogy at The Academy of Arts - University of Novi Sad (2007-2011), and English language philology at "The Faculty of Legal and Business Studies Lazar Vrkatić, PhD” in Novi Sad (2012). At The Association of Centres for Interdisciplinary and Multidisciplinary Studies and Research (ACIMSI) of The University of Novi Sad (UNS) (in 2013), Marić finished her postgraduate master studies in Management in Education. She is currently a student of a doctoral study programme in Teaching Methodology at the Faculty of Philosophy (UNS). She has a working experience in Music School "Isidor Bajić" as a teacher of different music subjects and English language, and in both Primary and Secondary Ballet School as a piano accompanist of Classical Ballet classes, and a teacher of Solfeggio, Music Culture and History of Music. 